\title{
Possibilities of Using Landfill Biogas for Heating Agricultural Greenhouses in Crete-Greece
}

\author{
John Vourdoubas \\ Department of Natural Resources and Environmental Engineering, \\ Technological Educational Institute of Crete, \\ 3 Romanou str., 73133, Chania, Crete, Greece.
}

Received: February 1, 2016 Accepted: February 14, 2016 Published: February 21, 2016

doi:10.5296/jas.v4i2.9066

URL: http://dx.doi.org/10.5296/jas.v4i2.9066

\begin{abstract}
Biogas is currently produced in Crete-Greece from the two existing landfills in the island, as well as from the sewage treatment plants in Chania and Heraklion. Biogas produced in the two treatment plants is already used for co-generation of heat and power. However, since the quantities of landfills biogas and its energy content are significant, it can be used in the future either for heat production or for heat and power generation. Generated power can be fed into the grid and the produced heat can be used from a heat consumer. Since large heat consumers are not located nearby the existing landfills, there is the possibility for the creation of agricultural greenhouses in the surrounding agricultural areas which can utilize the generated heat. Landfill in Heraklion has an average biogas production of $1.43 \times 10^{7} \mathrm{NM}^{3} /$ year, almost five times higher than the landfill in Chania and the totally recoverable biogas from the two landfills can generate $16.73 \mathrm{GWh} /$ year of electricity, in the case of a CHP plant, and enough heat for heating 15.4 hectares of modern greenhouses. In the case of direct heat generation, recoverable landfill biogas can heat 24.41 hectares of modern greenhouses. Since the global warming potential of methane is much higher than $\mathrm{CO}_{2}$, energy exploitation of landfills biogas in Crete will result in environmental benefits compared with its direct emission to the atmosphere.
\end{abstract}

Keywords: Biogas, co-generation, Crete, greenhouses, heat, landfill, methane, power

\section{Introduction}

Biogas constitutes a renewable fuel produced mainly from organic wastes which are anaerobically digested with bacteria. Since its heating value is not negligible and its global warming potential high, its use for heat and power generation is considered as a good option for its utilization. Currently, biogas in Crete-Greece is produced from the two landfills 
in Chania and Heraklion and from the two sewage treatment plants which operate in the same cities. Biogas from those treatment plants is currently utilized for heat and power generation. An assessment of the pollutants from the Akrotiri landfill site in Chania-Western Crete has been presented (Chalvatzaki et al, 2009, Chalvatzaki et al, 2010). The landfill consists of two cells: the first with capacity of $440,000 \mathrm{M}^{3}$, operated during the period 2003-2007 with annual acceptance of wastes 80,000 tn/year and the second with capacity of $660,000 \mathrm{M}^{3}$, operated from 2007 until 2015 with annual acceptance rate of 85,000 tn/year. Three different landfill gas emissions models have been used for the assessment of the gas emissions rates. The authors have predicted a rather constant biogas production rate over the period 2008-2025 using the reliable Land GEM model. They have estimated an average biogas emission rate of $1.1 \times 10^{6} \mathrm{NM}^{3} /$ year for cell A and $1.8 \times 10^{6} \mathrm{NM}^{3} /$ year for cell $\mathrm{B}$. A report on the management of olive mill wastes in Greece has been presented (Chartzoulakis, 2014). Among different treatment methods, anaerobic biological processing mostly driven by bacteria with biogas production has a high construction and operation cost and it is not affordable from small-size, family-based olive mills. A report on current situation and perspectives of biogas production in Greece has been published (Zafiris, 2007). According to him, biogas production in sewage treatment plant in Chania is $1,085 \mathrm{NM}^{3} /$ day and in the respective plant in Heraklion 3,200 $\mathrm{NM}^{3} /$ day. Investigation of biogas produced in the landfill of Heraklion Crete for power generation has been presented (Tsave et al, 2008, Karapidakis et al, 2010 ). An average biogas production from the landfill over the period 2006-2026 of $1,636.68 \mathrm{NM}^{3} / \mathrm{h}$ has been estimated and assuming that $75 \%$ of the produced biogas can be recovered, its energy content is $55.95 \mathrm{GWh} /$ year. Assuming that the power generation efficiency is $25 \%$, the average electric power generation from this landfill gas ( LFG) is estimated at $13.99 \mathrm{GWh} /$ year. The power plant capacity for generation of $13.99 \mathrm{GWh} /$ year has been estimated at 1.6 MW. An evaluation of biogas utilization for energy generation from the sewage treatment plant in Heraklion, Crete has been presented (Tsagarakis et al, 2006). An average biogas production of $2,040 \mathrm{NM}^{3} /$ day over a period of 5.5 years has been found. The average electricity generation from the biogas was 2,039.3 KWh/day. Generated power corresponds to $15.9 \%$ of the consumed electricity of the sewage treatment plant, but the authors believe that with proper process optimization it could reach at $39 \%$. An experimental application of LFG for heating a greenhouse with roses cultivation in France has been reported (Jaffrin et al, 2003). In an experimental greenhouse of $300 \mathrm{M}^{2}$, they have used LFG to heat the space and the purified burnt gases were enriching the greenhouse atmosphere. They have reported that crop productivity increases due to $\mathrm{CO}_{2}$ enrichment, are more important to greenhouse economics, compared to the benefit resulting from the reduction of heating costs due to the use of LFG. The authors have underlined the potential for developing greenhouses located nearby landfill sites. The possibility of power generation from LFG using traditional and innovative technologies have been presented (Bove et al, 2006). They have compared traditional technologies like internal combustion engine, gas turbine, plant with organic Rankine cycle and Stirling engine with innovative technologies like molten carbonate fuel cell and solid oxide fuel cell. They have concluded that, although internal combustion engines have the poorest environmental performance, they are the most widely technology used due to economic reasons. A technical, economic, and environmental analysis 
of biogas utilization has been reported (Murphy et al, 2004). They have investigated the possibilities of using LFG for CHP production and for transport fuel production in Ireland. The authors have concluded that the production of transport fuel is more economic than the utilization of biogas in a CHP plant depending on transport fuel taxes. They have reported also that the conversion of LFG to carbon dioxide through direct burning, significantly reduces greenhouse-gas production as compared with the emission of LFG to the atmosphere. Energy recovery combined with greenhouse effect reduction from landfills has been investigated (Lombardi et al, 2006). The authors have compared the traditional use of LFG for power generation with innovative technologies using its direct feeding to a fuel cell, the production of a hydrogen rich gas with steam reforming to feed a stationary fuel cell and to feed a vehicle fuel cell. They have concluded that steam reforming of LFG and subsequently use of the gas, reduces overall greenhouse gas emissions. A report on methane generation in landfills has been presented (Themelis et al, 2007). According to their findings an approximate production of $50 \mathrm{NM}^{3}$ of methane per ton of municipal solid wastes landfilled could be a conservative estimation. However, currently only $10 \%$ of this methane potential worldwide is captured and utilized. In USA, $70 \%$ of the captured LFG is currently utilized for generation of heat and power. The authors report that global generation of methane from landfills is estimated at 50 million tons and from them 45 million tons are emitted to the atmosphere, which approx. are equivalent to 1 billion tonnes of $\mathrm{CO}_{2}$, since $\mathrm{CH}_{4}$ has 23 times higher global warming potential than $\mathrm{CO}_{2}$. Four different technologies which produce energy from municipal solid wastes including incineration, gasification, generation of biogas and utilization in a CHP plant and generation of biogas and conversion to transport fuel have been investigated (Murphy et al, 2004). Both biogas technologies require less investment costs than the thermal conversion technologies and have smaller gate fees but the transport technology is cheaper. Energy production from LFG in Central Italy has been reported (Caresana et al, 2011). The authors have investigated the profitability of five alternative configuration plants for power generation and for CHP. They have concluded that internal combustion engines is the most cost effective technology compared to other innovative technologies. In order to utilize the co-produced heat in industrial facilities and to profit from that, they have installed the CHP plant in some distance from the landfill, which results in additional costs. Environmental aspects of landfill gas utilization for power generation have been studied ( Qin et al, 2001). The high concentration of $\mathrm{CO}_{2}$ in LFG (typically 40-50 \%) negatively impacts combustion efficiency and stability. Experimental and theoretical investigation has proved that $\mathrm{CO}_{2}$ increases the $\mathrm{NO}$ emissions per gram of $\mathrm{CH}_{4}$ consumed. The authors concluded that its combined use with natural gas will result in more efficient energy utilization and less emissions. The energy potential of the biogas produced by an urban waste landfill in Southern Spain has been investigated (Zamorano et al, 2007). In a sealed landfill in Granada, Spain, LFG yield was estimated at 250-550 $\mathrm{NM}^{3} / \mathrm{h}$, with $\mathrm{CH}_{4}$ content of $45 \%$. The authors have found that its utilization for power generation with a 624 $\mathrm{KW}$ engine is profitable having a high internal recovery rate. The present study highlights the importance and the challenges of utilizing LFG in Crete-Greece for energy generation and the possibility of creating greenhouses nearby the existing landfills, in order to utilize the produced heat resulting in higher profitability of biogas exploitation for energy generation. 


\section{Heating requirements of agricultural greenhouses}

Modern greenhouses require energy for heating, cooling, lighting, and operation of various electric devices. Most of the energy used is consumed for their heating, which can reach at $95,31 \%$ of the total energy used (Vourdoubas, 2015). Heating requirements of greenhouses depend on the climate, the construction type and the cultivated crops. Northern European greenhouses, which are heavy constructions, need more energy for their heating than Mediterranean greenhouses, which are simple constructions and the climate is mild. The most common fuels currently used for heating them include fuel oil, heating oil and natural gas and only a small percentage of them utilize renewable energies or low carbon energy technologies for their heating although some of them are cost effective (Vourdoubas, 2015). Greenhouse heating can increase crops productivity, improve the quality of the products and increase profitability. Heating cost constitutes a significant part of the total crops production cost in the greenhouses and the selection of the suitable fuel as well as the proper heating technology can influence their profitability. Although the heating requirements of a greenhouse vary depending on many factors, for a modern and well equipped greenhouse of $1,000 \mathrm{M}^{2}$ located in Chania-Crete-Greece and in order to control the indoor temperature at $20-22{ }^{\circ} \mathrm{C}$ during the winter and at $26-27{ }^{\circ} \mathrm{C}$ during the summer, heating needs have been estimated at 220,000 $\mathrm{KWh}$ /year and the peak heating load at $185.8 \mathrm{KW}$ (Vourdoubas, 2015).

\section{Use of renewable energies for heating greenhouses}

Various renewable energy sources have been used for heating greenhouses including solar energy, geothermal energy and biomass. Low carbon and high efficiency energy technologies like heat pumps and co-generation systems have been also used including waste heat reuse for that. Many of these technologies are cost effective and their use results in the decrease of heating costs in agricultural greenhouses. Use of renewable energies and high efficiency energy technologies in heating them, results in many environmental and social benefits, including the mitigation of greenhouse gas emissions in the atmosphere and the use of local renewable energy resources instead of imported fossil fuels. Renewable energies can either cover part or all of the heating requirements of modern greenhouses without requiring additional fuels. Solar energy can cover part of the heating and cooling requirements and it is occasionally used in commercial greenhouses. Biomass and direct geothermal heating are currently used for covering all their heating needs. Co-generation systems and waste heat reuse have been also used commercially. However, although many sustainable energy technologies are currently mature, reliable and cost effective, their use in greenhouses should be propagated more. In order to increase their use, governmental support including awareness raising, training and technical support as well as financial incentives among the farmers should be offered. Various renewable energies are site depended and this limits their use for energy generation to nearby located greenhouses.

\section{Biogas production n Crete}

Biogas is currently produced in Crete from the existing landfills in Heraklion (Tsave et al, 2008, Karapidakis et al, 2010) and in Chania (Chalvatzaki et al, 2009, Chalvatzaki et al, 2010). It is also produced in the sewage treatment plants in the same cities. Various studies 
have proved the technical viability of the production of biogas from olive mills liquid wastes in Crete. However, although these wastes are highly polluted having very high $\mathrm{BOD}_{5}$ and COD values, their anaerobic digestion for biogas production is not cost effective and they are not processed in this way in Crete. Biogas produced from the sewage treatment plants in Chania and Heraklion is currently used for co-generation of heat and power. Power is sold to the grid and the heat is used for heating the sludge digestors, in order to keep the sludge in the desired temperatures. However, LFG is not currently utilized for heat or power generation or for co-generation of heat and power since the co-produced heat cannot be utilized in the landfills or nearby, since they are located in remote areas away from urban or industrial activities. However due to high global warming potential of biogas, it must be burnt instead of being emitted to the atmosphere (EU directive 1999/31/EC ). The existence of available agricultural land nearby the landfills and the mild climate of Crete, offer the opportunity to create greenhouses which can be heated with the biogas produced in the landfills. In that case LFG can be used either directly for heating greenhouses or it can be used for co-generation of heat and power. Generating only power from the LFG and feeding it to the grid is not economically attractive, if heat is not co-generated. However, if the generated power can be sold to the grid and heat is co-produced, which is used for heating greenhouses, the co-generation option is more profitable. The combination of biogas production from wastes, biogas utilization for CHP and the use of the generated heat and power in different applications, promotes recycling economy, industrial ecology and overall sustainability. Biogas produced from the landfills in Chania and Heraklion as well as from the sewage treatment plants in these cities is presented in table 1.

Table 1: Biogas production in Crete from two landfills and two sewage treatment plants located in Chania and Heraklion Prefectures

\begin{tabular}{|l|l|l|l|l|l|}
\hline $\begin{array}{l}\text { Source } \\
\text { biogas } \\
\text { production }\end{array}$ & $\begin{array}{l}\text { Biogas } \\
\text { production } \\
\left(\mathrm{NM}^{3} / \text { year }\right)\end{array}$ & $\begin{array}{l}\text { Energy } \\
\text { content of the } \\
\text { produced } \\
\text { biogas } \\
\text { (Kcal/year })\end{array}$ & $\begin{array}{l}\text { Biogas which } \\
\text { can be } \\
\text { recovered } \\
\left(\mathrm{NM}^{3} / \text { year }\right)\end{array}$ & $\begin{array}{l}\text { Energy } \\
\text { content of the } \\
\text { recovered } \\
\text { biogas } \\
\text { (Kcal/year })\end{array}$ & $\begin{array}{l}\text { of } \\
\text { total } \\
\text { in } \\
\text { Crete }\end{array}$ \\
\hline $\begin{array}{l}\text { Landfill in } \\
\text { Chania, cell 1 }\end{array}$ & $1.1 \times 10^{6}$ & $4.9 \times 10^{9}$ & $8.25 \times 10^{5}$ & $3.7 \times 10^{9}$ & 5.87 \\
\hline $\begin{array}{l}\text { Landfill in } \\
\text { Chania, cell 2 }\end{array}$ & $1.8 \times 10^{6}$ & $8.1 \times 10^{9}$ & $1.35 \times 10^{6}$ & $6 \times 10^{9}$ & 9.55 \\
\hline $\begin{array}{l}\text { Landfill in } \\
\text { Heraklion }\end{array}$ & $1.43 \times 10^{\prime}$ & $6.4 \times 10^{10}$ & $1.08 \times 10^{\prime}$ & $4.8 \times 10^{10}$ & 76.21 \\
\hline $\begin{array}{l}\text { Sewage } \\
\text { treatment plant } \\
\text { in Chania }\end{array}$ & $3.96 \times 10^{5}$ & $1.77 \times 10^{9}$ & $2.97 \times 10^{5}$ & $1.33 \times 10^{9}$ & 2.12 \\
\hline
\end{tabular}




\begin{tabular}{|l|l|l|l|l|l|}
\hline $\begin{array}{l}\text { Sewage } \\
\text { treatment plant } \\
\text { in Heraklion }\end{array}$ & $1.17 \times 10^{\circ}$ & $5.24 \times 10^{9}$ & $8.77 \times 10^{5}$ & $3.93 \times 10^{9}$ & 6.25 \\
\hline Total & $1.88 \times 10^{\prime}$ & $8.4 \times 10^{10}$ & $1.41 \times 10^{\prime}$ & $6.3 \times 10^{10}$ & 100 \\
\hline
\end{tabular}

${ }^{1}$ data from Zafiris, ${ }^{2}$ data from Tsave et al., ${ }^{3}$ data from Chalvatzaki et al., Biogas energy content 4,475 Kcal/ $\mathrm{NM}^{3}$, Biogas recovery rate $75 \%$

\section{Co-generation of heat and power from LFG}

LFG can be used for co-generation of heat and power having high overall efficiencies in the order of 70-80\%. Electric efficiency of $25 \%$ and heat efficiency of $50 \%$ can be easily achieved. The generated electricity can be fed into the grid and the co-generated heat can be sold to a heat consumer located nearby the landfill. However this is not always possible since landfills are located in remote areas without many activities nearby. The economics of power generation from LFG are considerably improved in the case that power and heat are co-produced. Current feed-in tariffs for power generated from LFG and fed into the grid in Crete is at $0.09945 € / \mathrm{KWh}_{\mathrm{el}}$. Current price for heat is estimated in Crete at $0.06 € / \mathrm{KWh}_{\mathrm{th}}$. Since the landfills in the island are located in surrounding areas suitable for the creation of greenhouses, they can profit from their operation since they will have access to a rather cheap heat source. Various technologies which can be used for power generation from LFG are presented in table 2.

Table 2: Different technologies for power generation or co-generation of heat and power from LFG

\begin{tabular}{|l|l|}
\hline Technology type & Use \\
\hline Internal combustion engine & Most common \\
\hline Gas turbine & Common \\
\hline Steam turbine & limited \\
\hline Stirling engine & Very limited in commercial scale \\
\hline Fuel cells & Very limited in commercial scale \\
\hline
\end{tabular}

\section{Use of LFG for heating greenhouses in Crete-Greece}

LFG can be used for heating greenhouses which could be created nearby the existing landfills since the surrounding land is suitable for these cultivations. In achieving that, biogas can either be used only for heating purposes or it can be used for CHP and the produced heat to be used for heating them. The economics and the technologies used in those two cases are different. Since a renewable fuel is generated from organic wastes and it is used afterwards for energy generation and crops production, it results in energy recycle in a sustainable way. Various different processes are interwoven including organic wastes digestion with biogas production, power and heat generation from the biogas, power fed to the grid and use of the produced heat for food or flowers production. 


\subsection{Use of LFG for heat generation and use of the produced heat in greenhouses}

Direct burning of the LFG requires simple technology and the produced heat can be used for heating greenhouses. The burnt gases can also be reused after treatment for enriching the greenhouse atmosphere with $\mathrm{CO}_{2}$ which will result in higher crops productivity. The area of the greenhouses which can be heated in this case is presented in table 3 .

Table 3. Area of greenhouses which can be heated after LFG burning from the existing landfills in Crete

\begin{tabular}{|l|l|l|l|l|}
\hline Landfill & $\begin{array}{l}\text { Energy content of } \\
\text { the } \\
\text { biogas (Kcal/year) }\end{array}$ & $\begin{array}{l}\text { Usefull heat } \\
\text { after burning of } \\
\text { biogas } \\
\text { (Kcal/year) }\end{array}$ & $\begin{array}{l}\text { Heating needs } \\
\text { of greenhouses } \\
\text { (Kcal/hectare } \\
\text { year) }\end{array}$ & $\begin{array}{l}\text { Area } \\
\text { greenhouses } \\
\text { which can be } \\
\text { heated } \\
\text { (Hectares) }\end{array}$ \\
\hline $\begin{array}{l}\text { Landfill in } \\
\text { Heraklion }\end{array}$ & $4.8 \times 10^{10}$ & $3.84 \times 10^{10}$ & $1.89 \times 10^{9}$ & 20.3 \\
\hline $\begin{array}{l}\text { Landfill in } \\
\text { Chania, cell 1 }\end{array}$ & $3.7 \times 10^{9}$ & $2.96 \times 10^{9}$ & $1.89 \times 10^{9}$ & 1.57 \\
\hline $\begin{array}{l}\text { Landfill in } \\
\text { Chania, cell 2 }\end{array}$ & $6 \times 10^{9}$ & $4.8 \times 10^{9}$ & $1.89 \times 10^{9}$ & 2.54 \\
\hline Total & $5.77 \times 10^{10}$ & $46.16 \times 10^{10}$ & & 24.41 \\
\hline
\end{tabular}

Efficiency of biogas burning for direct heat production $80 \%$

\subsection{Use of LFG for CHP and use of the produced heat in greenhouses}

Co-generation of heat and power using LFG has the advantage that the generated electricity can be fed into the grid and the co-produced heat can be used for heating greenhouses which can be created nearby the landfills. Taking into account that the electric efficiency of the CHP plant will be $25 \%$ and the heat efficiency $50 \%$, the area of the greenhouses which could be heated is presented in table 4.

Table 4. Area of greenhouses which can be heated with the heat produced in the CHP plants using LFG of the existing landfills in Crete

\begin{tabular}{|l|l|l|l|l|l|}
\hline Landfill & $\begin{array}{l}\text { Energy } \\
\text { content of } \\
\text { the } \\
\text { recovered } \\
\text { biogas } \\
(\text { Kcal/year })\end{array}$ & $\begin{array}{l}\text { Generated } \\
\text { heat from } \\
\text { the CHP } \\
\text { plant Kcal/year }) \\
(\text { ) }\end{array}$ & $\begin{array}{l}\text { Generated } \\
\text { electricity } \\
\text { from the } \\
\text { CHP plant } \\
(\text { GWh/year } \\
)^{2}\end{array}$ & $\begin{array}{l}\text { Heating needs } \\
\text { of } \\
\text { greenhouses } \\
\text { (Kcal/hectare } \\
\text { year) }\end{array}$ & $\begin{array}{l}\text { Area of } \\
\text { greenhouses } \\
\text { which can } \\
\text { be heated } \\
\text { ( Hectares) }\end{array}$ \\
\hline $\begin{array}{l}\text { Landfill in } \\
\text { Heraklion }\end{array}$ & $4.8 \times 10^{10}$ & $2.4 \times 10^{10}$ & 13.92 & $1.89 \times 10^{9}$ & 12.7 \\
\hline $\begin{array}{l}\text { Landfill in } \\
\text { Chania, }\end{array}$ & $3.7 \times 10^{9}$ & $1.85 \times 10^{9}$ & 1.07 & $1.89 \times 10^{9}$ & 0.98 \\
\hline
\end{tabular}




\begin{tabular}{|l|l|l|l|l|l|}
\hline cell 1 & & & & & \\
\hline $\begin{array}{l}\text { Landfill in } \\
\begin{array}{l}\text { Chania, } \\
\text { cell 2 }\end{array}\end{array}$ & $6 \times 10^{9}$ & $3 \times 10^{9}$ & 1.74 & $1.89 \times 10^{9}$ & 1.72 \\
\hline Total & $5.77 \times 10^{10}$ & $28.8 \times 10^{10}$ & 16.73 & & 15.4 \\
\hline
\end{tabular}

${ }^{1}$ Heat efficiency $50 \%,{ }^{2}$ Power efficiency $25 \%$

\section{Environmental considerations}

It is estimated that methane landfills emissions correspond at $13 \%$ of the total antropogenic methane emissions (Themelis et al, 2007 ). Since methane has 23 times the global warming potential of $\mathrm{CO}_{2}$, it is concluded that the warming potential of biogas emitted from the existing landfills in Crete is significant. Assuming that the methane concentration in biogas is $50 \%$ and the methane density is $0.714 \mathrm{~kg} / \mathrm{NM}^{3}$ it is concluded that methane production in the landfills in Crete is 5,033.7 tons/year and it has the global warming potential of 115,775 tons $\mathrm{CO}_{2}$ annually.

\section{Conclusions}

Modern and well equipped greenhouses are energy intensive crops production systems. Use of renewable energy sources like solar energy, biomass and geothermal energy for heat and power generation in them can improve their sustainability and profitability as well. Various sustainable energy technologies are currently reliable, mature and cost effective and they can be used for energy generation in agricultural greenhouses. The existing two landfills in Crete, in Prefectures of Chania and Heraklion, produce biogas which is not currently used for energy generation although its value is relatively high. Both landfills produce approx. $92 \%$ of the biogas production in Crete and the rest is produced in the two sewage treatment plants in Chania and Heraklio. LFG can be used for power generation which can be fed into the grid with attractive feed-in tariffs. However the possibility of CHP from LFG and the use of co-produced heat for heating greenhouses can improve the process economics compared with power generation only, provided that the heat can be consumed locally. Alternatively, LFG can be used for direct heat production, if a large heat consumer like a greenhouse located nearby the landfill could utilize the produced heat. Fortunately, both landfills in Crete are located in surrounding agricultural areas where greenhouses can be created. The landfill in Heraklion produces almost five times more biogas than the landfill in Chania and its direct heat production can be used for heating of 20.3 hectares of greenhouses. Biogas from the landfill in Chania can be used for heating of 4.11 hectares of greenhouses. In the case that LFG is used for CHP, Heraklion landfill can generate $13.92 \mathrm{GWh} /$ year electricity and enough heat for heating 12.7 hectares of greenhouses. LFG from Chania s landfill can generate 2.81 $\mathrm{GWh} /$ year electricity and enough heat for heating 2.7 hectares of greenhouses. Recycle of the cleaned burnt gases in the greenhouse atmosphere will result in additional benefits due to higher crops productivity. Future use of LFG for energy generation in Crete apart from economic benefits will result in environmental benefits, since the global warming potential of $\mathrm{CH}_{4}$ is much higher than $\mathrm{CO}_{2}$. 


\section{References}

Alexakis,G., The Region of Crete and the EU's 2030 Energy and Climate Goal, 42nd General Assembly of CPMR, 24-26 September 2014, Umea, Sweden. retrieved on 10/1/2016 from http://www.crpm.org/pub/agenda/2677_ag_2014_session_6_ppt_alexakis.pdf

Bove, R., \&Lunghi, P. (2006). Electric power generation from landfill gas using traditional and innovative technologies. Energy Conversion and Management, 47(11-12), 1391-1401. http://dx.doi.org/10.1016/j.enconman.2005.08.017

Caresana, F., Comodi, G., Pelagalli, L., Pierpaoli, P., \&Vagni, S. (2011). Energy production from landfill biogas: An italian case. Biomass and Bioenergy, 35(10), 4331-4339. http://dx.doi.org/10.1016/j.biombioe.2011.08.002

Chalvatzaki, E., \&Lazaridis, M. (2009). Assessment of emissions of air pollutants from the Akrotiri landfill site ( Chania,Greece). In 11th International Conference on Environmental Science and Technology Chania, Crete, Greece, 3 - 5 September 2009 : CEST 2009 (pp. 2218-2225). Athens: Global Network for Environmental Science and Technology (Global-NEST).

Chalvatzaki,E. \& Lazaridis,M., ( 2010).Estimation of greenhouse gas emissions from landfills : Application to the Akrotiri landfill site (Chania-Greece).Global nest,12(1),108-116.Retrieved

from http://journal.gnest.org/sites/default/files/Journal\%20Papers/108-116_681_Lazaridis_12-1.pd $\mathrm{f}$

Chartzoulakis,K., (2014). Management of Olive Mill Wastes in Greece "olive oil production technologies and their environmental impact" 12 April 2014, Izmir, Turkey. retrieved on 10/1/2016 from http://www.iamawaste.org/assets/chartzoulakis_izmir-2014.pdf

Council Directive 1999/31/EC of 26 April 1999 on the landfill of waste [1999] OJ L182/1

Esen, M., \&Yuksel, T. (2013). Experimental evaluation of using various renewable energy sources for heating a greenhouse. Energy and Buildings, 65, 340-351. http://dx.doi.org/10.1016/j.enbuild.2013.06.018

Zafiris,Ch., (2007). Biogas in Greece:Current situation and Perspectives, European Biogas Workshop Esbjerg, 14-16 June 2007,retrieved on 10/1/2016 from Christos Zafiris, Biogas in Greece:Current situation and Perspectives, European Biogas Workshop Esbjerg, 14-16 June 2007.

Jaffrin, A., Bentounes, N., Joan, A.., \&Makhlouf, S. (2003). Landfill Biogas for heating Greenhouses and providing Carbon Dioxide Supplement for Plant Growth. Biosystems Engineering, 86(1), 113-123. http://dx.doi.org/10.1016/s1537-5110(03)00110-7

Karapidakis, E. S., Tsave, A. A., Soupios, P. M., \&Katsigiannis, Y. A. (2010). Energy efficiency and environmental impact of biogas utilization in landfills. International Journal of Environmental Science \& Technology, 7(3), 599-608. http://dx.doi.org/10.1007/bf03326169

Lombardi, L., Carnevale, E., \&Corti, A. (2006). Greenhouse effect reduction and energy recovery from waste landfill. Energy, 31(15), 3208-3219. http://dx.doi.org/10.1016/j.energy.2006.03.034 


\section{$\triangle$ Macrothink}

Journal of Agricultural Studies

ISSN 2166-0379

2016, Vol. 4, No. 2

Murphy, J. D., \&McKeogh, E. (2004). Technical, economic and environmental analysis of energy production from municipal solid waste. Renewable Energy, 29(7), 1043-1057. http://dx.doi.org/10.1016/j.renene.2003.12.002

Murphy, J.., McKeogh, E., \& Kiely, G. (2004). Technical/economic/environmental analysis of biogas utilisation. Applied Energy, 77(4), 407-427.

http://dx.doi.org/10.1016/j.apenergy.2003.07.005

Qin, W., Egolfopoulos, F. N., \&Tsotsis, T. T. (2001). Fundamental and environmental aspects of landfill gas utilization for power generation. Chemical Engineering Journal, 82(1-3), 157-172. http://dx.doi.org/10.1016/s1385-8947(00)00366-1

Themelis, N. J., \& Ulloa, P. A. (2007). Methane generation in landfills. Renewable Energy, 32(7), 1243-1257. http://dx.doi.org/10.1016/j.renene.2006.04.020

Tsagarakis, K. P., \&Papadogiannis, C. (2006). Technical and economic evaluation of the biogas utilization for energy production at Iraklio Municipality, Greece. Energy Conversion and Management, 47(7-8), 844-857. http://dx.doi.org/10.1016/j.enconman.2005.06.017

Tsave, A. A., \&Karapidakis, E. S. (2008, May). Landfill Gas (LFG) Plants: An application on energy regarding environmental impact. Journal of optoelectronics and advanced materials, 10(5), 1277-1281. Retrieved from

http://karapidakis.chania.teicrete.gr/7205\%20\%202004,\%20An\%20application\%20on\%20en ergy\%20regarding\%20environmental\%20impact.pdf

Vourdoubas, J. (2015). Economic and Environmental Assessment of the Use of Renewable Energies in Greenhouses: A Case Study in Crete-Greece. Journal of Agricultural science, 7(10), 48-57. http://dx.doi.org/10.5539/jas.v7n10p48

Vourdoubas, J. (2015). Possibilities of using renewable energy sources for covering all the energy needs of agricultural greenhouses. Journal of Agricultural and Life Sciences, 2, 111-118. Retrieved 2015, from

http://www.jalsnet.com/journals/Vol_2_No_1_June_2015/14.pdf

Vourdoubas, J. (2015). Overview of Heating Greenhouses with Renewable Energy Sources a Case Study in Crete- Greece. Journal of Agriculture and Environmental Sciences, 4(1), 70-76. http://dx.doi.org/10.15640/jaes.v4n1a9

Zamorano, M., Ignacio Pérez Pérez, J., Aguilar Pavés, I., \& Ramos Ridao, Á. (2007). Study of the energy potential of the biogas produced by an urban waste landfill in Southern Spain. Renewable and Sustainable Energy Reviews, 11(5), 909-922. http://dx.doi.org/10.1016/j.rser.2005.05.007

\section{Copyright Disclaimer}

Copyright for this article is retained by the author(s), with first publication rights granted to the journal.

This is an open-access article distributed under the terms and conditions of the Creative Commons Attribution license (http://creativecommons.org/licenses/by/3.0/). 